\title{
半自然草原の保全と再生に向けた新しい取り組み
}

\author{
井上 雅仁 $^{1 *} \cdot$ 高橋 佳孝 $^{2}$ \\ 1 島根県立三瓶自然館・財団法人しま敉自然と環境財団 \\ 694-0003 島根県大田市三瓶町多根 1121-8 \\ 2 近畿中国四国農業研究センター 694-0013 島根県大田市川合町吉永 60

\section{New movement in activities for conservation and restoration of \\ semi-natural grassland} \\ Masahito Inoue $^{1^{*}}$ and Yoshitaka Takahashi \\ ${ }^{1}$ The Shimane Nature Museum of Mt. Sanbe, 1121-8 Tane, Sanbe-cho, Ohda, Shimane
694-0003 Japan
${ }^{2}$ National Agricultural Research Center for Western Region, 60 Yoshinaga, Ohda, Shimane \\ 694-0013 Japan
}

Key Words: Semi-natural grassland, Restoration of semi-natural grassland, New sense of value, Partnership

キーワード : 半自然草原，草原再生，新しい価値観，協働

失われゆく日本の草原

我が国では，比較的温暖多雨な気候条件を反映し て，高山，岩角地，風衝地などの特殊な条件下で成 立する自然草原などを除けば，森林が極相として成 立すると考えられている。かつて広く分布していた 草原の多くは，人為的作用により植生遷移が止めら れることで維持されてきた二次的な植生といえる. 自然草原と区別するために，二次草原あるいは半自 然草原と呼ばれる。

これら半自然草原が維持されてきた人為的作用と しては，採草，放牧，火入れなどがある。採草は， 牛馬の飼料や敷き草，肥料用の草，さらに茅莫き屋 根や炭俵の材料を得るために行われてきた。牛馬は かつて，農耕や運搬のための労働力として不可欠な 存在で，飼料の確保は大切な仕事であった。また糞 は敷き草と混ざり合うことで厩肥となり，水田の肥 料となった。筆者らがフィールドとする島根県三瓶

*連絡先 : inoue@nature-sanbe.jp
山麓のある集落では，昭和の初め頃は約 840 戸のう ち実に 670 戸の家が牛を飼っており，頭数は 1,700 頭を越えていた (佐比売村誌). 農閑期は周囲の山野 に放牧して，飼育にかかる手間を大幅に省いていた。 地域の農畜産を支えた草原を維持することは, 地域 社会にとって当たり前なことであり, その最も効率 的な手段が火入れであった，早春に火が入ることで, 草原のヤブ化・灌木化の原因となる木本類の成長が 阻害され, その一方でイネ科草本の芽吹きが促進さ れた。

このように草原は人々の生活に久くことのできな い場であったため（西脇 2006），地域の共有財産と して，多くは地域コミュニティによって継続的に維 持管理されてきた（飯國ほか 2005）。

ところが，高度経済成長期を迎えると，工業生産 の拡大, 農耕機械の普及, 農畜産物の輸入などによ り, 草原を取り巻く状況は一変した。耕耘機などの 農耕機械が農家に広まるにつれ，労役としての牛馬 
は不要なものになっていく，そして集落から家畜が 消えると飼料を得るための採草は必要なくなり，化 学肥料の普及も緑肥を得るための採草の減少に拍車 をかけた。草利用の低下と時を同じくして，拡大造 林政策が展開され, 多くの草原は造林地一と変えら れた。地域の農畜産を支える場として国土面積の約 1 割を占めていた草原は（永見山 1995），このような 変遷を辿りながら現在は $1 \%$ 以下にまで減少してし まった（高橋・中越 1999 ; 小椋 2006）。

\section{見直される草原の価値}

生産の場としての役割は薄れつつあるなか, 近年 では, 草原のもつ様々な価值が再認識されつつある.

例えば，草原が作り出す広々とした風景は, 観光 資源として大きな可能性を有している。「阿蘇くじゅ う国立公園」の阿蘇地域や久住地域,「大山隠岐国立 公園」の蒜山地域, 隠岐地域, 三瓶山などは, 国立 公園への指定要件に, 草原景観や牧歌的景観が織り 込まれている。風致的に優れた自然を指定した国立 公園の中に，これだけの草原が含まれていることか ら，いかに私たち日本人が好む風景であるかが想像 できよう。阿蘇地域では, 年間 1,900 万人の観光客 が訪れるが, その目当ては雄大な草原景観である. 経済効果の試算によると，草原が維持されることに 対する総支払意志額が数十億円以上にのぼるとの報 告もある（小路ほか 1999 ; 矢部 2001 ; 新保 2001).

各地に残っている草原は, 絶滅が危惧される生物 が数多く生息する環境であることもわかってきた. オキナグサ, キキョウ, ヒゴタイなど草原を生育地 とする草花のなかには, 全国各地で姿を消しつつあ る種も少なくない（日本植物分類学会編 1993）。ま た草原を生息地とするチョウ類の多くが，各都道府 県のレッドデータブックに掲載されている（井村 2008）。これら希少な動植物がすむ草原は, 面積的に は小規模であるが, 絶滅危惧植物のホットスポット としての可能性が指摘されている（藤井 1999 ; 兼子 ほか 2009)。草原がもつ生物多様性保全上の価值に ついては, 現在, 筆者らは西日本における草原研究 者と共同で解明を進めているところであり，機会を 改めて報告したい.

草原の草資源の利用も見直されつつある. かつて のような膨大な需要はないものの, 茅莫きの伝統家 屋の保全や修復に必要な屋根用のカヤの需要は大き く, 良質のものは高価で取引されている。 また, 肥
料や飼料としての利用も続いており, 阿蘇地域では ススキなどの野草を堆肥の原料として, 高品質の野 菜, 花茾などの栽培が行われている（大滝 2001）. 近年では, 地球温暖化対策や循環型社会の実現が求 められるなか, バイオマス生産能力が高く, 生産過 程でのエネルギー投入量の少ない草本エネルギー植 物には，大きな期待が寄せられている（高橋 2008 ; 熟谷谷 2008).

このように，資源採取の目的に加え，いまではそ れ以上に多彩な価值をもつことを背景に, これらの 生態系サービスの供給が持続するよう, 全国各地で 草原を保全・再生する動きが広まりつつある.

\section{草原の保全と再生に向けて}

かつて草原利用が人々の生活に必要であった頃と は異なり，近年では，地域の資源を得る場としての 価值が薄れ, 生業としての草原への関わりは減少し てきた。 さらに, 農山村では, 海外産の安価な農畜 産物の輸入拡大による農畜産の衰退, 地元住民の高 齢化などで, 慢性的に草原管理の担い手不足が生じ ている。

そのため, 今後の草原保全・再生を進めるにあたっ ては, 単に昔の仕組みにすがるだけでなく, 新しい 価值観に基づいた，新たな体制による管理や利用の 仕組みが必要となっている. 例えば, 我が国で最大 規模の草原を誇る阿蘇においては, 都市住民の参画 が進められ, 新しいスタイルでの野焼きや防火帯切 りが実施されている（山内・高橋 2002）.

このように, 地域住民以外の参画によって草原管 理が実施されている事例は, 萌芽的だが全国各地に 着実に広がりつつあり, 今後の取り組みを考えるに 当たり非常に有益な情報を提供するであろう。そこ で本特集では，対象とする草原の規模は異なるもの の, 半自然草原を保全・再生するために行われてい る取り組み,またはこれらの取り組みに関連するト ピックについて紹介してもらう.

熊本県の阿蘇地方では, 全国に先駆けて都市住民 が草原管理へ参加する「野焼き支援ボランティア」 の仕組みが作られ（山内・高橋 2002），2005 年には 自然再生推進法に基づき「阿蘇草原再生協議会」が 設立され（阿蘇草原再生協議会 2007）, 草原保全・ 再生の事業が進められている。草原に関わりのある 食べ物のブランド化, 草資源を地産地消する仕組み 作り, 地元牧野組合員による地域調查など, 取り組 
みはますます多様になっている. 草原再生の規模, 関わるメンバーの数や多彩さ, さらに種の保全から 地域振興にいたる活動の幅広さは我が国の草原再生 の中でも際立っており, 多くの示唆を与えてくれる. 同協議会の会長を務めている高橋氏に, 市民との連 携が進んでいる阿蘇の取り組みについて報告いただ $<$.

広島県北広島町に位置する雲月山では, 2005 年 4 月，6年ぶりに山焼きが再開され，そこには地域住 民のほか, 小学生, ボランティア, 地域博物館が加 わり，新しい協働体の姿があった。ただし，山に火 が放たれるまでには, 各主体が納得する目的の設定, 地域の合意形成, ボランティアの調整など, 多くの 課題が生じた。雲月山は, これらの課題をクリアし ながら山焼きが再会された地域であり, その後の地 域への波及効果, 参加者の意識変化なども詳細に追 跡されており, 各地の草原保全・再生の手本となる ものである. 博物館の学芸員としてこれらの動きに 深く関わってきた白川氏に, 山焼きの再開に至るま での経緯, 再会前後での各主体の変化などを報告い ただく.

阿蘇, 北広島いずれにおいても, 草原保全や再生 が進められてきた中で, 鍵となるのが, 複数の主体 の存在, それらの緩やかな連携, そして調整役の存 在といえよう。草原保全が行われている複数の地域 で，中心的役割を果たすリーダーの動きを中心に取 り組みを整理することで, 再生への手順や留意点が 判明してくる(小串・鎌田 2007). このような地域リー ダーの動きを一般化したプロセスは，新たな活動を 始める際の羅針盤となり, 今後の活動を検討する際 にはチェックリストとなろう。草原保全が進められ る様々な地域に出向き, ヒヤリングを実施してきた 小串氏に, 地域リーダーという視点から草原再生の 仕組みづくりのプロセスについて報告いただく.

多くの半自然草原は, かつては集落共用の場で あったため, 土地の所有や, 放牧・採草などの権利 が複雑に絡夕合った場でもある。草原保全を進めて いく上で, このような利権の調整も避けて通ること はできない課題である。草原管理へのボランティア の参加など地域住民以外の主体の関わりは，「新しい 入り会」など新たな枠組みを目指す動きを生じさせ る一方, 草資源の受益者が一部の個人に限定される など，ミスマッチも生じている. 阿蘇や三瓶山にお ける草原管理の問題を社会学的な視点から研究して きた飯國氏に, コモンズ論的な視点から半自然草地
の管理のあり方について報告をいただく. 草原再生の取り組夕は, 単に草原の希少種やそれ らが生育・生息する草原環境を再生することだけで なく, 草原と地域社会との多様で豊かな関係の再生 を目指すものである. 自然と人間, 草原を巡る人間 と人間の関係は, 時代の流れのなかで不確実性を伴 い，合意点も常に変化しつつある．このような「摇 らぎ」を受け入れ, 状況に応じて変えられる「順応 性を確保する仕組み」が重要である、いずれの報告 も, 草原の保全・再生一向けていまだ試行錯誤の過 程であり，その協働のあり方を問う示唆に富むもの である. 本特集が, 今後の草原の保全や再生の一助 になれば幸いである。

\section{引用文献}

阿蘇草原再生協議会. 2007. 阿蘇草原再生全体構 想阿蘇の草原を未来へ. 42pp. 阿蘇草原再生 協議会, 熊本.

藤井伸二. 1999. 絶滅仜惧植物の生育環境に関する 考察. 保全生態学研究 4: 57-69.

飯國芳明・諸岡慶昇・新保輝幸. 2005. 森のコモンズ・ 海のコモンズ (1). 海洋と生物 27: 472-477.

井村 治. 2008.レッドリスト分析による草原性チョ ウ類保全のための評価. 日本草地学会誌 54(1): 45-56.

兼子伸吾 - 太田陽子 - 白川勝信 - 井上雅仁 - 堤道生 渡邊園子・佐久間智子・高橋佳孝. 2009. 中国 5 県の RDB を用いた絶滅危惧植物における生育環境 の重要性評価の試み. 保全生態学研究 14: 125-129. 小串重治・鎌田磨人. 2008. 二次草地の再生を支え る社会システムに関する検討. ランドスケープ研 究 71: 885-892.

永見山幸男. 1995. 国土土地利用の概要. アトラス 日本列島の環境変化 (西川治監修), 1-16. 朝倉書 店, 東京.

日本植物分類学会編. 1993.レッドデータブック日 本の絶滅危惧植物. 141pp. 農村文化社, 東京.

西脇亜也. 2006. 農業の復興とともに草原を再生す る. エコソフィア 18: 34-39.

小椋純一. 2006. 日本の草地面積の変遷. 京都精華 大学紀要 30: 159-172.

大滝典雄. 2001. 野生草種の多様な利用. 近畿中国 四国農業研究センター畜産草地部資料 H13-1. 1-3. 小路 敦・須山哲男 - 佐々木寬幸. 1999. 仮想市場 
評価法（CVM）による野草地景観の経済的評価. 日本草地学会誌 45(1): 88-91.

新保輝幸. 2001。シバ草地がもたらす外部経済：仮 想旅行費用法による三瓶草原の景観・レクリエー ション価值の経済評価, 山地畜産を軸とした環境 保全型アグロフォレストリ・システムの確立（平 成 $11 \sim 12$ 年度科学研究補助金（基盤研究 (B)(2) 研究成果報告書, 研究代表者: 飯國芳明) 第 3 章, p61-92.

高橋佳孝・中越信和. 1999. ヒトがつくりあげた日 本の草地. 遺伝 53(10): 16-20.

高橋佳孝. 2008. 草原バイオマスの古くて新しい利 用, 森林環境 2008 草と木のバイオマス, p91-103. 森林文化協会, 東京.

熟谷いづみ. 2008. バイオマス利用とウエットラン ドの保全・利用, 森林環境 2008 草と木のバイオマ ス, p104-110. 森林文化協会, 東京.

矢部光保. 2001. 阿蘇草原の保全価值評価と環境支 払い, 中山間地域等への直接支払いと環境保全（合 田素行編著), p185-206. 家の光協会, 東京.

山内康二・高橋佳孝. 2002. 阿蘇千年の草原の現状 と市民参加による保全へのとりくみ. 日本草地学 会誌 48(3): 290-298. 